\title{
Inhibition of Digestive Enzyme and Stimulation of Human Liver Cells (HepG2) Glucose Uptake by Date Seeds Extract
}

\author{
Hira Shakoor, Fatima Abdelfattah, Khaula Albadi, Mentalla Adib, Jaleel Kizhakkayil, \\ and Carine Platat $(\mathbb{D})$
}

Department of Food, Nutrition and Health, College of Food and Agriculture, United Arab Emirates University, P.O. Box 15551, Al Ain, UAE

Correspondence should be addressed to Carine Platat; platatcarine@uaeu.ac.ae

Received 19 May 2020; Accepted 6 July 2020; Published 29 July 2020

Academic Editor: Armando Zarrelli

Copyright (C) 2020 Hira Shakoor et al. This is an open access article distributed under the Creative Commons Attribution License, which permits unrestricted use, distribution, and reproduction in any medium, provided the original work is properly cited.

Type 2 diabetes mellitus is increasing worldwide, and the United Arab Emirates is presenting one of the world's highest prevalence rates. Dietary polyphenols exert an antidiabetic effect by modulating carbohydrates digestion and cellular glucose uptake. Due to their particularly high content in polyphenols, date seeds represent a potential antidiabetic agent. This study aims to determine if date seed polyphenols inhibit the activity of the enzymes ( $\alpha$-amylase and $\alpha$-glucosidase), responsible for the digestion of carbohydrates and modulating the glucose uptake by human liver cells. In vitro activity of the intestinal $\alpha$-glucosidase, pancreatic $\alpha$-amylase, the glucose uptake by HepG2 cells, and the expression of GLUT4 and AMPK analyzed by western blotting (with and without date seeds extract). Our result showed that the maximum enzymes inhibition was obtained with $400 \mu \mathrm{g} / \mathrm{mL}$ and $900 \mu \mathrm{g} / \mathrm{mL}$ DSE for $\alpha$-amylase and $\alpha$-glucosidase, respectively. The HepG2 cell viability significantly decreased up to $80 \%$ at $4000 \mu \mathrm{g} / \mathrm{mL}$ DSE. The expression of GLUT4 was higher at $100 \mu \mathrm{g} / \mathrm{mL}$ DSE (with insulin and without insulin). However, the expressions of P-AMPK and AMPK were increased by DSE, mainly in a non-insulin-dependent manner. Therefore, DSE, by inhibiting carbohydrate digestion and stimulating glucose uptake by HepG2, can potentially demonstrate the therapeutic potential for diabetes management.

\section{Introduction}

Type 2 diabetes mellitus (T2DM) is a complex metabolic disorder characterized by hyperglycemia resulting from abnormal glucose metabolism. It is associated with many complications, including hypertension, retinopathy, nephropathy, and neuropathy [1]. T2DM is now among the top ten causes of death in the world [2]. It is continuously increasing despite significant therapeutic advancement. Globally, 425 million individuals are suffering from T2DM, which may increase to 693 million by 2045 [2]. In the United Arab Emirates (UAE), the prevalence of T2DM is $18.7 \%$, one of the greatest in the world and expected to reach $21.4 \%$ by 2030 [3]. This trend adds a tremendous burden to societies and healthcare systems. Hence, it is urgent to identify new strategies to stop this progression.
Postprandial hyperglycemia is an independent risk factor for T2DM regulated in two ways: the intestinal absorption of glucose, which depends on the breaking down of carbohydrates by enzymes including $\alpha$-glucosidase and $\alpha$-amylase, and the cellular uptake of glucose [4]. The liver plays a central role in the regulation of glucose homeostasis either by storing glucose as glycogen or releasing it into the blood after intestinal absorption. Further, the liver is the place where glycogen breakdown, glycolysis, and neoglucogenesis can occur [5]. Nowadays, many drugs are available for T2DM that can help decrease blood glucose levels, but those drugs have many side effects. Therefore, the therapeutic approach should be taken into consideration for the management of T2DM [6]. Interestingly, diet and a healthy lifestyle have a significant role in the prevention of T2DM. Diverse underlying mechanisms have been 
identified, including retarding the absorption of glucose by inhibiting carbohydrates hydrolyzing enzymes ( $\alpha$-amylase and $\alpha$-glucosidase) and increasing the expression of glucose transporters in various human cells [7]. Dietary compounds likely to exert such effects would represent a promising alternative to drugs in the prevention and treatment of T2DM.

Polyphenols are a large and heterogeneous group of phytochemicals (plant-based food) such as flavonoids, phenolic acids, lignans, and stilbenes $[8,9]$. Several hundred different polyphenols have been identified in vegetables, fruits, and cereals $[10,11]$. Admittedly, polyphenols reported having many beneficial health properties such as antioxidant, antibacterial, antiviral, anti-inflammatory, and anticancerous [12]. Polyphenols are known to exhibit antidiabetic properties due to their ability to influence glucose metabolism. For instance, polyphenols have been shown to modulate digestive enzymes involved in carbohydrate digestion, stimulate insulin secretion by $\beta$-cells, activate insulin receptors, and regulate glycemia by stimulating glucose uptake in insulin-sensitive tissue and by modulating hepatic glucose output [11-13]. Such properties have been reported for polyphenols from coffee, guava, tea, whortleberry, olive oil, propolis, chocolate, red wine, grape seed, and cocoa [14]. Remarkably, polyphenols can inhibit digestive enzymes like $\alpha$-amylase and $\alpha$-glucosidase, leading to a reduced release of glucose after a meal $[15,16]$. In addition, polyphenols can modulate glucose transportation by stimulating GLUT transporters, among which the insulin-sensitive GLUT4 is notable. Polyphenols have been involved in promoting GLUT4 translocation in muscles and adipose tissues $[17,18]$. Phenolic compounds could also restore the phosphorylated level of AMPK (PAMPK) in hepatic cells to maintain glucose homeostasis $[19,20]$. Activation of AMPK in the liver, skeleton muscle, and adipose tissue helps to promote glucose uptake, insulin sensitivity, and fatty acid oxidation [21, 22]. Consequently, any plant or plant-derived food rich in polyphenols present a potential for the prevention and the management of T2DM.

Date seeds are a widely available by-product in the Middle East region. There are about 40 million date trees in the UAE, and the country is one of the largest producers of dates in the world [23]. Interestingly, date seeds are particularly rich in polyphenols, with a content higher than other famous polyphenol-rich food products like grape or tea [24-27]. Depending on the variety, a concentration in polyphenols between 1864.82 and $4768.87 \mathrm{mg}$ GAE/100 g was reported [26]. A detailed exploration of the polyphenolic compounds identified flavan-3-ols, especially catechins and epicatechins, as the most abundant in date seeds, with up to $50.18 \mathrm{~g} / \mathrm{kg}$ flavan-3-ols in the Khalas variety [24, 25]. A detailed qualitative and quantitative identification of polyphenols in date seeds was performed using HPLC-mass spectrometry and found abundant amounts of flavan-3-ols, phenolic acids, flavones, and flavonols [28]. In vitro and in vivo studies also illustrated the antioxidant property in date seeds [29-31]. However, the possible effect of date seeds on glucose homeostasis still remained unknown.
Therefore, our study's primary purpose was to determine if date seeds extract (DSE) could contribute to glucose homeostasis by modulating glucose intestinal digestion and glucose uptake by human liver cells and, then, to investigate some potential mechanisms underlying these possible effects.

\section{Materials and Methods}

2.1. Date Seed Extract (DSE) Preparation. Date palm (Phoenix dactylifera L.) seeds of the Khalas variety were used in this trial. The Al Foah, Company-Emirates Dates factory, provided date seeds. Dates were collected randomly from tamr (fully ripe dates) batches at the end of the season, with no preference to size, color, appearance, or firmness.

Date seeds powder was prepared by milling cleaned and dried date seeds. The powder was sieved by BZS 200 sieve machine and particles of less than 300 microns were used for the study as powder. DSE was prepared by extracting the powder with ethanol: water $(1: 1)$ solution. The extract was filtered using Whatman filter paper, was reduced under nitrogen, and was vacuum dried to yield the extract. The detailed polyphenolic contents of DSE have already been described in one of our previous works [28].

\subsection{Carbohydrate Digestion Inhibition}

2.2.1. $\alpha$-Amylase Inhibitory Assay. The assay was carried out using a modified procedure version of McCue and Shetty, 2004 [32]. A total of $250 \mu \mathrm{L}$ of date seed extract $(0-1500 \mu \mathrm{g} / \mathrm{mL})$ was placed in a tube and $250 \mu \mathrm{L}$ of $0.02 \mathrm{M}$ sodium phosphate buffer ( $\mathrm{pH}$ 6.9) containing $\alpha$-amylase solution $(0.5 \mathrm{mg} / \mathrm{mL})$ was added. The tubes' content was preincubated at $25^{\circ} \mathrm{C}$ for 10 mins, after which $250 \mu \mathrm{L}$ of $1 \%$ starch solution in a $0.02 \mathrm{M}$ sodium phosphate buffer $(\mathrm{pH}$ 6.9) was added timed intervals. The reaction mixtures were incubated at $25^{\circ} \mathrm{C}$ for $10 \mathrm{~min}$. The reaction was stopped by adding $500 \mu \mathrm{L}$ of dinitrosalicylic acid (DNS) reagent and then incubated in boiling water for $5 \mathrm{~min}$ and cooled to room temperature. The content of each test tube was diluted with $5 \mathrm{~mL}$ of distilled water. The absorbance was measured at $540 \mathrm{~nm}$ in a spectrophotometer (Spectrumlab S23A, Globe Medical, England). The control was prepared in the same except that the extract was replaced with distilled water. The $\alpha$-amylase inhibitory activity was calculated as in the following equation:

$$
\text { \%inhibition }=\left\{\frac{(\mathrm{Ac}-\mathrm{Ae})}{\mathrm{Ac}}\right\} 100 \text {, }
$$

where Ac and Ae are the absorbance of the control and extract, respectively.

2.2.2. $\alpha$-Glucosidase Inhibitory Assay. The $\alpha$-glucosidase activity on the extract was determined according to the method described by Kim et al. using $\alpha$-glucosidase from Saccharomyces cerevisiae [33]. The substrate solution p-nitrophenyl glucopyranoside (pNPG) $(3.0 \mathrm{mM})$ was prepared in $20 \mathrm{mM}$ phosphate buffer, $\mathrm{pH}$ 6.9. $100 \mu \mathrm{L}$ of 
$\alpha$-glucosidase $(1.0 \mathrm{U} / \mathrm{mL})$ was preincubated with $50 \mu \mathrm{L}$ of the different concentrations of the extracts $(0-4000 \mu \mathrm{g} / \mathrm{mL})$ for 10 mins. Then $50 \mu \mathrm{L}$ of $3.0 \mathrm{mM}$ (pNPG) as a substrate dissolved in $20 \mathrm{mM}$ phosphate buffer ( $\mathrm{pH}$ 6.9) was added to start the reaction. The reaction mixture was incubated at $37^{\circ} \mathrm{C}$ for $20 \mathrm{mins}$ and stopped by adding $2 \mathrm{~mL}$ of $0.1 \mathrm{M}$ $\mathrm{Na}_{2} \mathrm{CO}_{3}$. The $\alpha$-glucosidase activity was determined by measuring the yellow-colored para-nitrophenol released from $\mathrm{pNG}$ at $405 \mathrm{~nm}$. The results (\% inhibition) are expressed as a percentage of the blank (control) as in the following equation.

$$
\text { \%inhibition }=\left\{\frac{(\mathrm{Ac}-\mathrm{Ae})}{\mathrm{Ac}}\right\} 100,
$$

where Ac and Ae are the absorbance of the control and extract, respectively.

2.3. HepG2 Liver Cells Culture. Culture in $75 \mathrm{~cm}^{2}$ cell culture flasks, at $37^{\circ} \mathrm{C}$, in a humidified atmosphere of $5 \% \mathrm{CO}_{2} / 95 \%$ $\mathrm{O}_{2}$, at a seeding density of approximately 105 cells $/ \mathrm{cm}^{2}$, in Eagle's minimal essential medium, was supplemented with $10 \% \mathrm{v} / \mathrm{v}$ heat-inactivated FBS and $100 \mathrm{U} / \mathrm{mL}$ penicillinstreptomycin. Cells grow until $80-90 \%$ confluence. Cells were used up to passage 20 for the experiments.

2.4. Cell Viability Test. HepG2 cells were cultured in the 96 wells plate $\left(1 \times 10^{4}\right.$ cells/well $)$ and incubated overnight. After 24 hours, they were treated with various concentrations (ranging from 0 to $4000 \mu \mathrm{g} / \mathrm{mL}$ ) of date seeds extract for 24 hours. $10 \mu \mathrm{L}$ of WST-1(4-[3-(4-Iodophenyl)-2-(4-nitrophenyl)-2H-5-tetrazolio]-1,3-benzene sulfonate) solution was added to each well and incubated further for 4 hours. The absorbance was measured with a spectrophotometer at $420 \mathrm{~nm}$ by using a microplate reader.

2.5. Cell Glucose Uptake. Glucose uptake was assayed according to the established protocol from a commercial glucose uptake kit (ab136955; Abcam). In brief, HepG2 cells were seeded $\left(1 \times 10^{5}\right.$ cells/well $)$ in a 24 -well plate overnight. After 24 hours, media was replaced with serum-free DMEM/ F12 medium and incubated overnight. Krebs-Ringer Phosphate-Hepes buffer was added with an incubation time of 40 minutes. Subsequently, cells were stimulated with 20 , 40 , and $100 \mu \mathrm{g} / \mathrm{mL}$ date seeds extract for 4 hours and insulin $(1 \mu \mathrm{M})$ (Sigma Aldrich, USA) for 15 minutes. Then, $10 \mathrm{mM}$ 2-deoxyglucose was added and incubated for an additional $20 \mathrm{~min}$. Cells were washed three times with cold PBS and lysed with extraction buffer, then frozen at $-80^{\circ} \mathrm{C}$ for $10 \mathrm{~min}$, and heated at $85^{\circ} \mathrm{C}$ for $40 \mathrm{~min}$. After cooling on ice for $5 \mathrm{~min}$, the lysates were neutralized by adding neutralization buffer. Centrifugation was done, and the remaining lysate was diluted with assay buffer. Finally, the end product was produced with an amplification step as per the kit protocol. Absorbance was measured at $412 \mathrm{~nm}$ by using a multiscan microplate reader.
2.6. GLUT4 and AMPK Protein Expression. HepG2 cells were seeded $\left(1 \times 10^{5}\right.$ cells/well $)$ in a 24 -well plate overnight and next day treated with DSE (40 and $100 \mu \mathrm{M})$ without insulin $(1 \mu \mathrm{M})$ for 4 hours. HepG2 cells were washed with phosphate buffer saline (PBS). $200 \mu \mathrm{L}$ of RIPA Cell lysis buffer $(50 \mathrm{mM}$ Tris- $\mathrm{HCl} \mathrm{pH} 7.4,150 \mathrm{mM} \mathrm{NaCl}, 1 \mathrm{mM}$ ethylenediaminetetraacetic acid, $1 \%$ Triton $\mathrm{X} 100,0.1 \%$ sodium dodecyl sulphate (SDS), $10 \mathrm{mM} \mathrm{NaF}, 1 \mathrm{mM} \mathrm{Na} \mathrm{VO}_{4}$, and $50 \mathrm{mM} \mathrm{Na} \mathrm{m}_{2} \mathrm{O}_{7}$ ) containing $1 \%$ protease inhibitor cocktail, $1 \mathrm{~mm}$ phenyl methyl sulfonyl fluoride (PMSF), and $10 \mathrm{~mm}$ dithiothreitol (DTT) was added to the cells. The cell lysates were centrifuged at $14,000 \mathrm{rpm}$ for $15 \mathrm{~min}$ at $4^{\circ} \mathrm{C}$. Total protein was determined by Bio-Rad protein assay, diluted with $6 \times$ loading buffer, and boiled at $100^{\circ} \mathrm{C}$ for 5 minutes. Loaded $40 \mu \mathrm{g} /$ lane of proteins samples, separated by SDS-PAGE, was transferred onto a nitrocellulose membrane by wet transfer using a Bio-Rad Electrotransfer apparatus. The membranes were blocked with milk for 1 hour at room temperature and immunoblotted using polyclonal primary antibodies against GLUT4, P-AMPK, AMPK, and $\beta$-actin antibodies (Cell signaling, USA). The membranes were incubated for 2 hours with primary antibodies and then with appropriate horseradish peroxidaseconjugated secondary antibodies for 1 hour. The band densities were detected by detecting the intensity of the band and using an enhanced chemiluminescence detection kit (Thermo, USA). The band densities were quantified using an image analyzer Quantity One System (Bio-Rad).

2.7. Statistical Analysis. Statistical analyses were performed by using the SPSS software v.25. Means \pm SD or \% were calculated, as appropriate. Experiments were done at least in triplicate; then the average was calculated. The statistical significance of experimental observations was determined using ANOVA followed by Dunnett (Figures 1-4(c)) and Tukey's posttest (Figure 5). Statistical significance was set at $p<0.05$.

\section{Results and Discussion}

Briefly, our data showed that DSE inhibited $\alpha$-amylase and $\alpha$-glucosidase and increased the expression of GLUT4, AMPK, and P-AMPK. These results support a potential role of DSE in the regulation of glucose homeostasis. These beneficial effects of DSE may be related to its high polyphenolic contents, especially the abundance of phenolics and flavan-3-ols for which antidiabetic properties have already been reported [25].

3.1. Polyphenolic Contents of DSE. Hilary et al. [28] characterized polyphenols from Khalas variety date seeds in three different forms: date seed pita bread (DSB), date seed powder (DSP), and date seed extract (DSE). The main compounds detected in all the three forms of date seeds were hydroxycinnamic acids, flavonols, flavanols, flavones, and hydroxybenzoic acids, which are mentioned in (Table 1). 


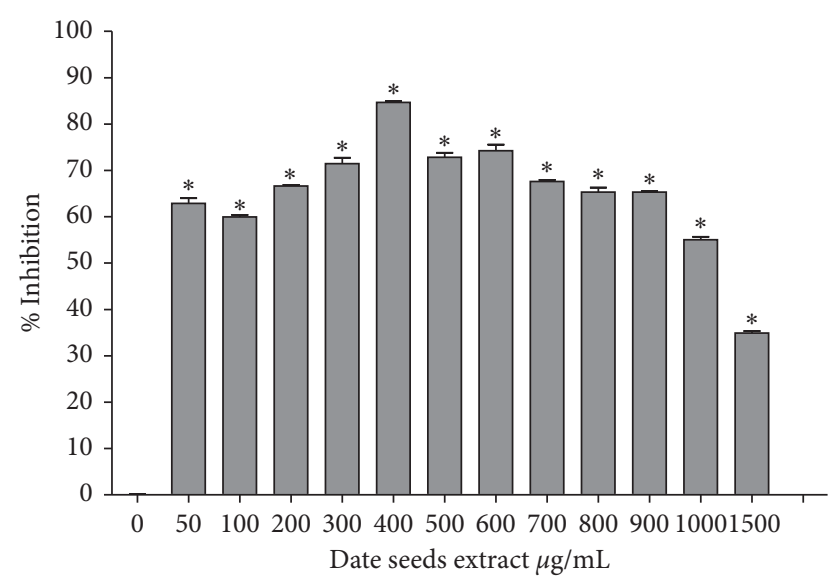

Figure 1: Effect of date seeds extract $(0-1500 \mu \mathrm{g} / \mathrm{mL})$ on $\alpha$-amylase activity ANOVA was used to compare between control $(0 \mu \mathrm{g} / \mathrm{mL}$ date seeds extract) and other date seeds extract concentrations. Values are the mean \pm SD calculated from three independent experiments. * Significantly $(<0.05)$ different from $0 \mu \mathrm{g} / \mathrm{mL}$ date seeds extract.

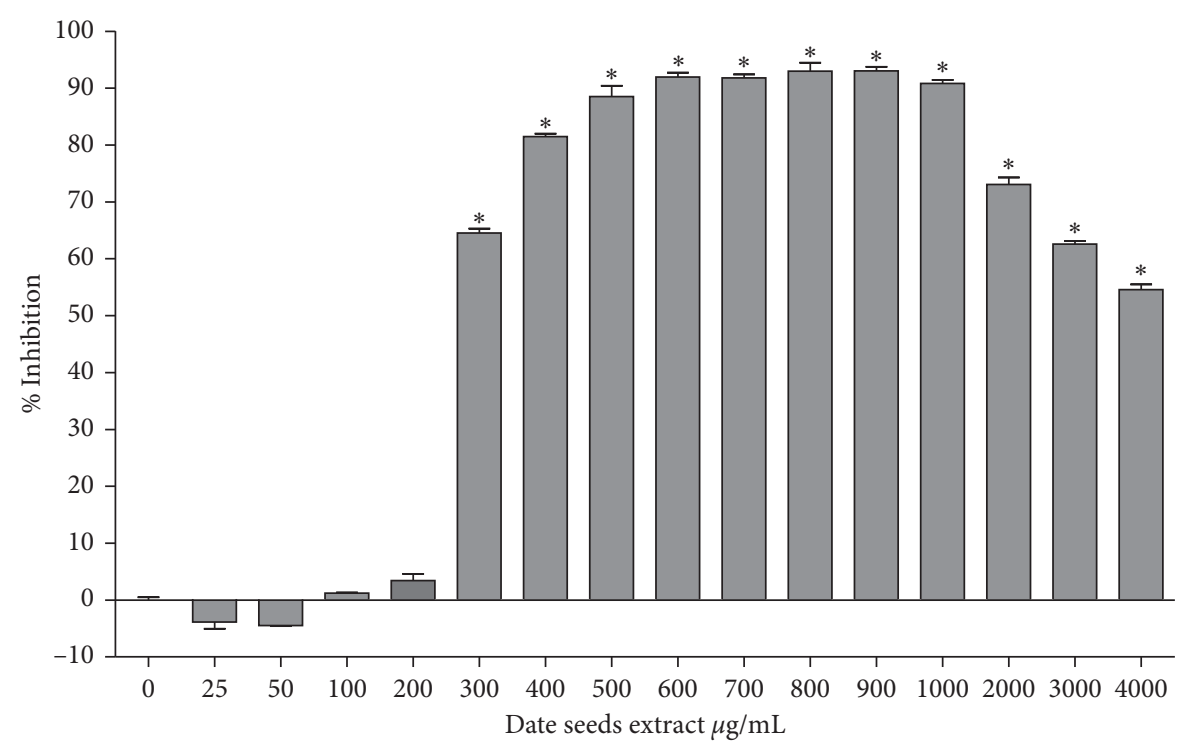

Figure 2: Effect of date seeds extract $(0-4000 \mu \mathrm{g} / \mathrm{mL})$ on $\alpha$-glucosidase activity ANOVA was used to compare between control $(0 \mu \mathrm{g} / \mathrm{mL}$ date seeds extract) and other date seeds extract concentrations. Values are the mean \pm SD calculated from three independent experiments. * Significantly $(<0.05)$ different from $0 \mu \mathrm{g} / \mathrm{mL}$ date seeds extract.

3.2. Inhibition of $\alpha$-amylase and $\alpha$-glucosidase Activity. The effect of DSE on glucose digestion was investigated in vitro by measuring the activity of the enzymes: $\alpha$-amylase and $\alpha$-glucosidase (with or without DSE). A significant percentage of inhibition of $\alpha$-amylase, compared to the control, was observed at different concentrations of DSE, starting from $50 \mu \mathrm{g} / \mathrm{mL}$ and up to $1500 \mu \mathrm{g} / \mathrm{mL}$ (Figure 1). The maximum level of inhibition of $\alpha$-amylase (84.68\%) was detected with $400 \mu \mathrm{g} / \mathrm{mL}$ DSE. Similarly, $\alpha$-glucosidase was inhibited by DSE (Figure 2), from $300 \mu \mathrm{g} / \mathrm{mL}$ to $4000 \mu \mathrm{g} / \mathrm{mL}$ DSE. The maximum level of inhibition $\alpha$-glucosidase (93.04\%) was detected at $900 \mu \mathrm{g} / \mathrm{mL}$ DSE.

The two digestive enzymes, $\alpha$-amylase and $\alpha$-glucosidase, are involved in the breakdown of starch (polysaccharide, oligosaccharide) into simpler substances like disaccharides and monosaccharides. Inhibiting these enzymes hinders starches catabolism, hence, digestion and absorption of carbohydrates, thereby reducing postprandial glucose concentration $[34,35]$. Evidence showed that other polyphenol-rich products like tea, rosemary, pears, cocoa, lentils, and berries could inhibit $\alpha$-amylase and $\alpha$-glucosidase activity [36-38]. It was found that $0.05 \mathrm{mg} / \mathrm{mL}$ of tea polyphenols was reported to inhibit $61 \% \alpha$-amylase and $\alpha$-glucosidase in vivo and in vitro conditions [39]. The maximum level of inhibition with DSE in our findings was $84.68 \%$ for $\alpha$-amylase and $93.04 \% \alpha$-glucosidase, which is higher than tea polyphenols in previous studies. Polyphenols like anthocyanins, cyanidin 3-arabinoside, caffeic acid, rosmarinic acid, resveratrol, catechol, and protocatechuic acid would possess the most potent activity against digestive 


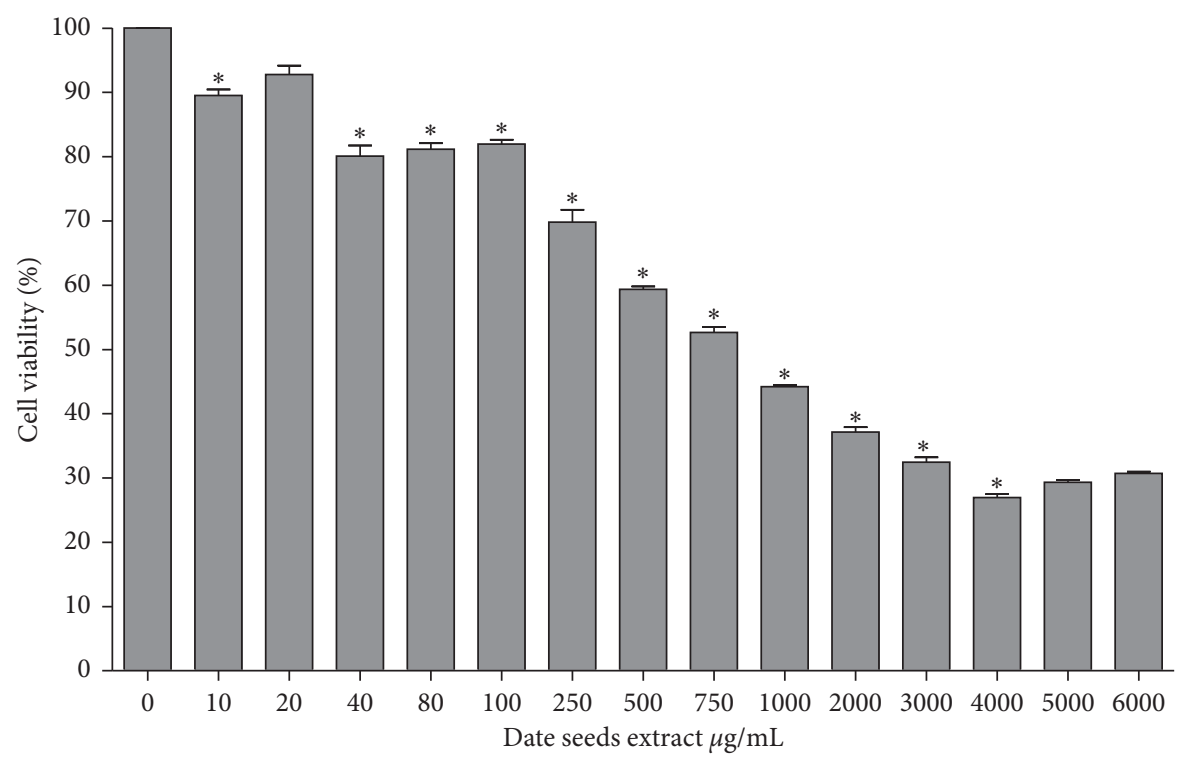

FIGURE 3: Effect of date seeds extract on HepG2 cell viability ANOVA was used to compare between control ( $0 \mu \mathrm{g} / \mathrm{mL}$ date seeds extract) and other date seeds extract concentrations. Values are the mean \pm SD calculated from three independent experiments. * Significantly $(<0.05)$ different from $0 \mu \mathrm{g} / \mathrm{mL}$ date seeds extract.

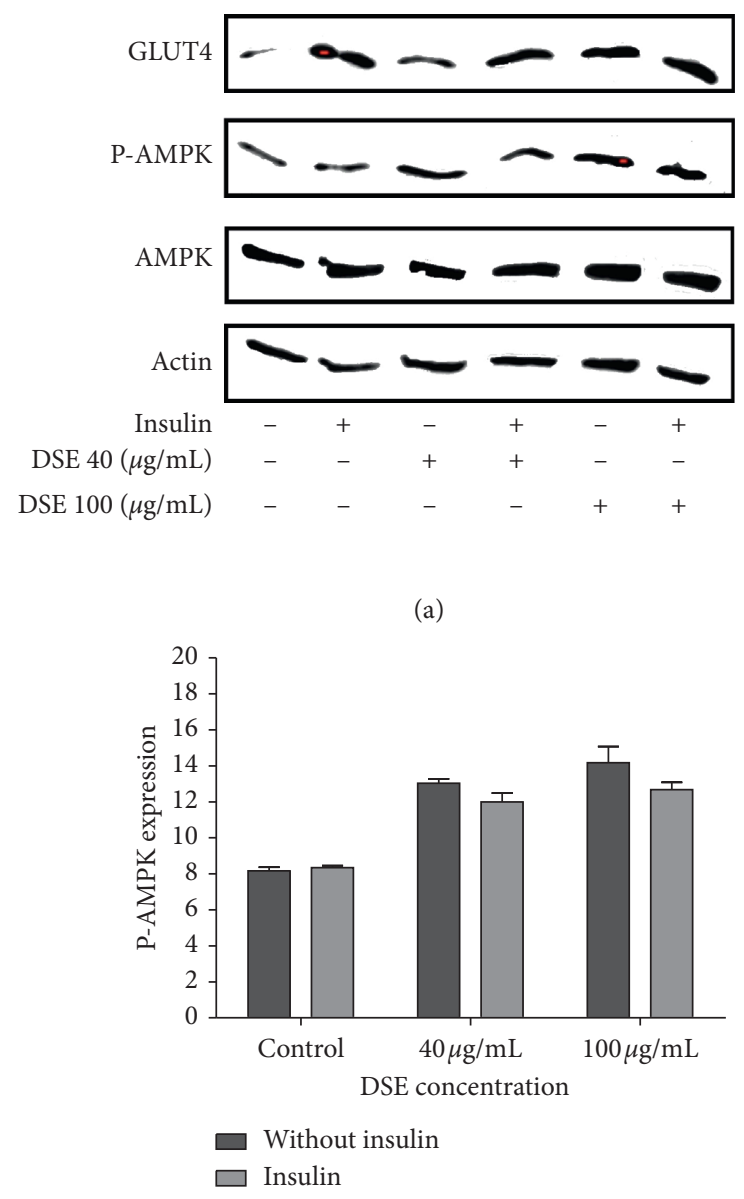

(c)

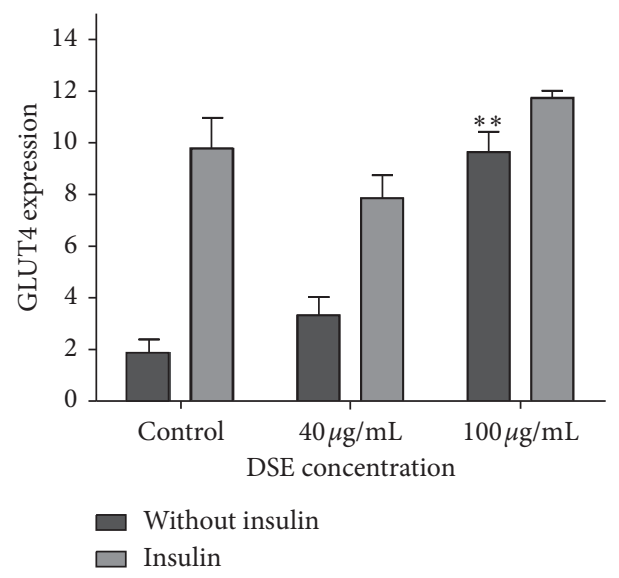

(b)

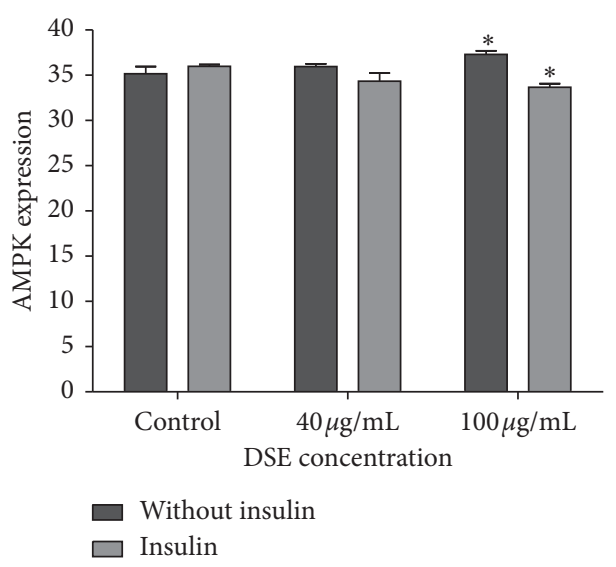

(d)

Figure 4: Effect of date seeds extract on the level of expression of GLUT4, AMPK, and P-AMPK proteins in human liver cells HepG2, with or without date seeds extract, in presence or not of insulin ANOVA was used to compare between control $(0 \mu \mathrm{g} / \mathrm{mL}$ date seeds extract, with and without insulin) and other date seeds extract concentrations. Values are the mean \pm SD. *Significantly $(<0.05),{ }^{* *}$ Highly significant $(<0.01)$ difference from $0 \mu \mathrm{g} / \mathrm{mL}$ date seeds extract. 


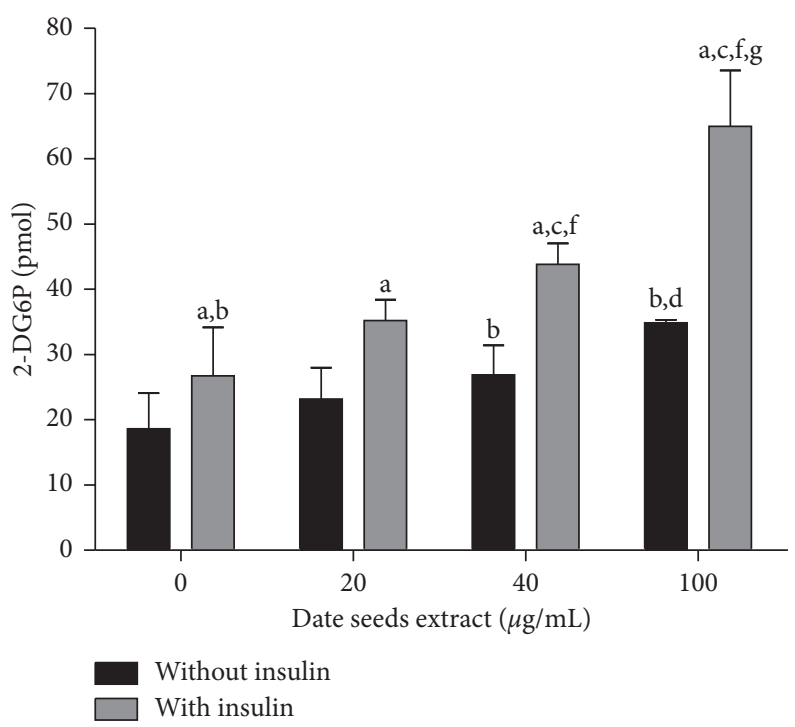

Figure 5: Effect of date seeds extract $(0,20,40$, and $100 \mu \mathrm{g} / \mathrm{mL})$ on glucose uptake by human liver cells HepG2. Values are the mean \pm SD calculated from three independent experiments. ${ }^{a}$ Statistically significant difference with the same condition without insulin. ${ }^{b}$ Statistically significant difference with the control without insulin. ${ }^{\mathrm{c}}$ Statistically significant difference with the control with insulin. ${ }^{\mathrm{d}}$ Statistically significant difference with DSE $20 \mu \mathrm{g} / \mathrm{mL}$ without insulin. ${ }^{\text {e}}$ Statistically significant difference with DSE $40 \mu \mathrm{g} / \mathrm{mL}$ without insulin. ${ }^{\text {f Stat- }}$ istically significant difference with DSE $20 \mu \mathrm{g} / \mathrm{mL}$ with insulin. ${ }^{g}$ Statistically significant difference with DSE $40 \mu \mathrm{g} / \mathrm{mL}$ with insulin.

TABLE 1: Polyphenols in different forms of date seeds.

\begin{tabular}{|c|c|c|}
\hline Polyphenols present in date seeds & Compounds detected & Forms of date seeds \\
\hline Hydroxycinnamic acids & $\begin{array}{c}\text { Caffeic acid Caffeic acid hexoside } \\
\text { N1,N8-dicaffeoyl spermidine Caffeoylshikimic acid } \\
\text { N1,N4-dicaffeoyl spermidine }\end{array}$ & $\begin{array}{c}D S E \\
D S P, D S E, D S B \\
D S P \text { and } D S E \\
\end{array}$ \\
\hline Flavonols & Quercetin Quercetin hexoside Quercetin hexoside sulphate Kaempferol hexoside & DSE, DSP \\
\hline Flavanols & $\begin{array}{c}\text { Procyanidin } \\
\text { Catechin Epicatechin }\end{array}$ & $\begin{array}{c}D S E, D S B \\
D S P, D S E, D S B\end{array}$ \\
\hline Flavones & Diosmetin-7-o-rutinoside 7-O-hexosyl diosmetin Diosmetin hexoside sulphate & $D S P, D S E$ \\
\hline Hydroxybenzoic acids & Protocatechuic acid $p$-hydroxybenzoic acid Syringic acid hexoside & $D S P, D S B, D S E$ \\
\hline
\end{tabular}

DSP: date seeds powder, DSE: date seeds extract, and DSB: date seeds bread.

enzymes [34, 37, 40, 41]. Interestingly, many of these compounds, including protocatechuic acid, are abundant in DSE, suggesting that the inhibitory effect of DSE on digestive enzymes could be attributed to their polyphenols.

3.3. Viability of HepG2 Cell. The potential cytotoxic effect of DSE was investigated, determining their impact on the viability of a human hepatoma cell line, HepG2. The HepG2 cell death rate was dose-dependent and about $20 \%$ of cell death was observed $40 \mu \mathrm{g} / \mathrm{mL}$ after the treatment with DSE for 24 hours of incubation. As the concentration of DSE is increasing, the inhibition of HepG2 cell proliferation increased significantly, especially from $750 \mu \mathrm{g} / \mathrm{mL}$ to $4000 \mu \mathrm{g} / \mathrm{mL}$. Maximum inhibition of about $80 \%$ was observed around $4000 \mu \mathrm{g} / \mathrm{mL}$ of DSE (Figure 3). Similarly, other studies showed that phenolic compounds such as flavonol, tannin, and anthocyanin inhibit the proliferation of HepG2 cells [42, 43]. Our result is similar to the findings of Yi et al., which reported 50\% inhibition of HepG2 cell population growth at $70 \mu \mathrm{g} / \mathrm{mL}$ of anthocyanin fractions [43]. Moreover, another study illustrated that food-derived phenolic content like chlorogenic acid and epicatechin reduced cell viability $15-20 \%$ after 18 hours of treatment [44].

3.4. Glucose Uptake by HepG2 Cells. The effect of DSE on glucose uptake by HepG2 cells was analyzed at a concentration of 20,40 , and $100 \mu \mathrm{g} / \mathrm{mL}$. Glucose uptake assay cells were exposed to the extract for only 4 hours and there was no influence on the cell viability with this concentration. So, these concentrations were not enough to make any changes in free glucose variation with cell death and ideal for the glucose uptake experiments. Glucose uptake by HepG2 cells (Figure 5) was significantly raised with DSE at $40 \mu \mathrm{g} / \mathrm{mL}$ and $100 \mu \mathrm{g} / \mathrm{mL}$ compared to the control without insulin. Similarly, in the presence of insulin, glucose uptake was increased with DSE at $40 \mu \mathrm{g} / \mathrm{mL}$ and even more at $100 \mu \mathrm{g} / \mathrm{mL}$, compared to the control with insulin. These effects were higher compared to the same concentrations without insulin. Our results agree with other studies on natural rich polyphenols ingredients like berries extract, showing that polyphenols 
like anthocyanins and proanthocyanidins stimulate glucose uptake by liver and muscle cells concentrations ranging from 0.1 to $10 \mu \mathrm{M}$ [45-47]. Beyond this, our results indicated that DSE could modulate the glucose uptake by HepG2 cells via both insulin and non-insulin-dependent pathways. It is known that dietary polyphenols influence peripheral glucose uptake in both insulin-sensitive and non-insulin-sensitive tissues [48-51]. In vitro studies showed that some polyphenolic compounds, including quercetin, resveratrol, epigallocatechin-3-gallate, and procyanidin, helped to improve insulin-dependent glucose uptake in muscle cells and adipocytes by translocation of glucose transporter, GLUT4, to plasma membrane mainly through induction of the AMPactivated protein kinase (AMPK) pathway [52-56].

3.5. Level of Expression of GLUT4, AMPK, and P-AMPK. The level of expression of the proteins GLUT4, AMPK, and P-AMPK was assessed by Western Blotting, for $40 \mu \mathrm{g} / \mathrm{mL}$ and $100 \mu \mathrm{g} / \mathrm{mL}$ DSE (Figure 4). As per the density of the bands (Figures 4(a)-4(c)), DSE significantly stimulated the expression of GLUT4 protein at $100 \mu \mathrm{g} / \mathrm{mL}$ without insulin. However, with insulin, the expression of GLUT4 also increased but did not reach statistical significance. Similarly, AMPK expression increased significantly at $100 \mu \mathrm{g} / \mathrm{mL}$ (with and without insulin). However, expression of P-AMPK protein increased with DSE in a dose-dependent manner and, to a greater extent, in the absence of insulin.

The translocation of GLUT4 is essential to maintain glucose homeostasis [57, 58]. GLUT4 translocation and AMPK phosphorylation increase insulin sensitivity, reduce insulin resistance, and prevent hyperglycemia with the help of polyphenols [55]. GLUT4 and AMPK were related by a mechanical pathway starting with the activation of AMPK by polyphenols and resulting in the induction of GLUT4 transporters translocation [52, 59-61]. The addition of insulin enhanced the effect of DSE on GLUT 4 level but not on AMPK level, which indicated that DSE could also translocate GLUT4 via the direct insulin-dependent mechanism, inducing the translocation of GLUT4 transporters [51, 62, 63]. AMPK is well-known to work as an energy sensor [64, 65]. In the case of energy demand, AMPK is activated, promoting glucose uptake, glycolysis, and fat oxidation [66]. Therefore, DSE because of it phenolic content could help in controling blood glucose concentration, thus, preventing T2DM by promoting glucose/fat catabolism and transport.

3.6. Limitations. This study is presenting some limitations. Here, the expression of GLUT4 was only measured, whereas, the effect of DSE on the expression of other transporters like GLUT1 (can be expressed to the same extent in cells and especially in liver cells) and GLUT 2 (primary glucose transporter in the liver) need to be analyzed. The overall modulation of glucose uptake will depend on the effect on each type of transporters. However, in adipose tissue, GLUT1 is expressed along with GLUT4 [67]. So, the translocation of these transporters is essential for the reduction of plasma glucose levels.
Similarly, among all digestive enzymes, only two were considered, that is, $\alpha$-amylase and $\alpha$-glucosidase because they are involved in carbohydrate digestion. However, inhibition of lipase activity is also crucial for controling obesity [68], which is a risk factor for diabetes. So, measuring the effects of date seed polyphenols on lipase inhibition will give us future direction.

Besides, after oral ingestion, polyphenols are likely to be transformed in the digestive tract and interact with the gut microbiota so that polyphenols in the blood circulation may differ significantly from the natural polyphenols, which is still unknown. However, in a recent human study, the metabolites of DSE polyphenols in urine were described, after oral ingestion [31]. It was reported that, in the first three hours of DSE intake, there was a significant increase in levels of aromatic acids metabolites such as protocatechuic acid, hydroxybenzoic acid, vanillic acid, vanillic acid sulphate, and ferulic acid sulphate as compared to the baseline. Seed polyphenols and metabolites have antioxidant effect because they upregulate enzymatic defence system, that is, GSH, and decrease oxidative stress [31].

\section{Conclusions}

In conclusion, our data highlighted the inhibitory effect of DSE on the activity of $\alpha$-amylase and $\alpha$-glucosidase, both human digestive enzymes responsible for the breakdown of dietary carbohydrates. Further, it was shown that DSE was able to stimulate the translocation of GLUT4 and increased the expression of energy sensor AMPK and P-AMPK, in cells from the liver (central organ for glucose and fat metabolism). It was also observed that phenolic compounds in DSE could inhibit HepG2 cell proliferation, knowing that DSE is relatively inexpensive and readily available [31]. DSE could be a possible alternative for the management of type 2 diabetes. Further research needs to be done to confirm the therapeutic potential of date seed polyphenols.

\section{Data Availability}

The data, in excel format and anonymous, to protect participants' privacy, are available upon request to the corresponding author.

\section{Conflicts of Interest}

The authors declare that there are no conflicts of interest.

\section{Authors' Contributions}

Hira Shakoor was responsible for writing the original draft and visualization. Fatima Abelfattah, Khaula Albadi, and Mentalla Adib were responsible for investigation and visualization. Jaleel Kizhakkayil was responsible for methodology, supervision, investigation, and resources. Carine Platat was responsible for conceptualization, funding acquisition, formal analysis, project administration, writing review, and editing. 


\section{Acknowledgments}

This project received a Summer Undergraduate Research Experience Grant from the United Arab Emirates University in 2018. This work was funded by United Arab Emirates University, SURE + UAEU grant 2018 (no. 31F11607_6_SURE+2018).

\section{References}

[1] A. A. Siddiqui, S. A. Siddiqui, S. Ahmad, S. Siddiqui, I. Ahsan, and K. Sahu, "Diabetes: Mechanism, pathophysiology and management-A review," International Journal of Drug Development, vol. 5, no. 2, pp. 1-23, 2013.

[2] N. H. Cho, J. E. Shaw, S. Karuranga et al., "IDF diabetes atlas: global estimates of diabetes prevalence for 2017 and projections for 2045," Diabetes Research and Clinical Practice, vol. 138, pp. 271-281, 2018.

[3] J. E. Shaw, R. A. Sicree, and P. Z. Zimmet, "Global estimates of the prevalence of diabetes for 2010 and 2030," Diabetes Research and Clinical Practice, vol. 87, no. 1, pp. 4-14, 2010.

[4] D. Nagmoti and A. Juvekar, "In vitro inhibitory effects of pithecellobium dulce (roxb.) benth. Seeds on intestinal $\alpha$-glucosidase and pancreatic $\alpha$-amylase," Journal of Biochemical Technology, vol. 4, no. 3, pp. 616-621, 2013.

[5] M. M. Adeva-Andany, N. Pérez-Felpete, C. FernándezFernández, C. Donapetry-García, and C. Pazos-García, "Liver glucose metabolism in humans," Bioscience Reports, vol. 36, no. 6, Article ID e00416, 2016.

[6] M. Bhat, S. S. Zinjarde, S. Y. Bhargava, A. R. Kumar, and B. N. Joshi, "Antidiabetic Indian plants: a good source of potent amylase inhibitors," Evidence-Based Complementary and Alternative Medicine, vol. 2011, Article ID 810207, 6 pages, 2011.

[7] J. Lindström, M. Peltonen, M. Peltonen et al., "Improved lifestyle and decreased diabetes risk over 13 years: long-term follow-up of the randomised Finnish diabetes prevention study (DPS)," Diabetologia, vol. 56, no. 2, pp. 284-293, 2013.

[8] M. Dellagreca, M. Isidori, M. Lavorgna, P. Monaco, L. Previtera, and A. Zarrelli, "Bioactivity of phenanthrenes from Juncus acutus on selenastrum capricornutum," Journal of Chemical Ecology, vol. 30, no. 4, pp. 867-879, 2004.

[9] A. Fiorentino, M. Dellagreca, B. D’Abrosca et al., "Lignans, neolignans and sesquilignans from cestrum parqui l'Her," Biochemical Systematics and Ecology, vol. 35, no. 6, pp. 392396, 2007.

[10] M. Greca Della, A. Fiorentino, P. Monaco, and L. Previtera, "Effusides I-V: 9, 10-dihydrophenanthrene glucosides from Juncus effusus," Phytochemistry, vol. 40, no. 2, pp. 533-535, 1995.

[11] D. R. Sharma, S. Kumar, V. Kumar et al., "Comprehensive review on nutraceutical significance of phytochemicals as functional food ingredients for human health management," Journal of Pharmacognosy and Phytochemistry, vol. 8, no. 5, pp. 385-395, 2019.

[12] N. Kumar and N. Goel, "Phenolic acids: natural versatile molecules with promising therapeutic applications," Biotechnology Reports, vol. 24, Article ID e00370, 2019.

[13] Y. Kim, J. Keogh, P. Clifton, Y. Kim, J. B. Keogh, and P. M. Clifton, "Polyphenols and glycemic control," Nutrients, vol. 8, no. 1, pp. 17-43, 2016.

[14] H. Cao, J. Ou, L. Chen et al., "Dietary polyphenols and type 2 diabetes: human study and clinical trial," Critical Reviews in
Food Science and Nutrition, vol. 59, no. 20, pp. 3371-3379, 2018.

[15] S. Liu, Z. Ai, F. Qu, Y. Chen, and D. Ni, "Effect of steeping temperature on antioxidant and inhibitory activities of green tea extracts against $\alpha$-amylase, $\alpha$-glucosidase and intestinal glucose uptake," Food Chemistry, vol. 234, pp. 168-173, 2017.

[16] K. C. S. Chang, Y. Tan, S. K. C. Chang, and Y. Zhang, "Comparison of $\alpha$-amylase, $\alpha$-glucosidase and lipase inhibitory activity of the phenolic substances in two black legumes of different genera comparison of $\alpha$-amylase, $\alpha$-glucosidase and lipase inhibitory activity of the phenolic substances in two black legumes," Food Chemistry, vol. 214, pp. 259-268, 2017.

[17] M. Ueda-Wakagi, R. Mukai, N. Fuse, Y. Mizushina, and H. Ashida, "3-O-Acyl-Epicatechins increase glucose uptake activity and GLUT4 translocation through activation of PI3K signaling in skeletal muscle cells," International Journal of Molecular Sciences, vol. 16, no. 7, pp. 16288-16299, 2015.

[18] D. J. Ooi, N. H. Azmi, M. U. Imam, N. B. Alitheen, and M. Ismail, "Curculigoside and polyphenol-rich ethyl acetate fraction of molineria latifolia rhizome improved glucose uptake via potential MTOR/AKT activated GLUT4 translocation," Journal of Food and Drug Analysis, vol. 26, no. 4, pp. 1253-1264, 2018.

[19] Q. Huang, L. Chen, H. Teng et al., "Phenolic compounds ameliorate the glucose uptake in HepG2 cells' insulin resistance via activating AMPK: anti-diabetic effect of phenolic compounds in HepG2 Cells," Journal of Functional Foods, vol. 19, pp. 487-494, 2015.

[20] H. O’Neill, “AMPK and exercise: glucose uptake and insulin sensitivity," Diabetes \& Metabolism Journal, vol. 37, no. 1, pp. 1-21, 2013.

[21] C.-L. Lin and J.-K. Lin, "Epigallocatechin gallate (EGCG) attenuates high glucose-induced insulin signaling blockade in human HepG2 hepatoma cells," Molecular Nutrition \& Food Research, vol. 52, no. 8, pp. 930-939, 2008.

[22] W. Y. Zhang, J.-J. Lee, I.-S. Kim, Y. Kim, J.-S. Park, and C.-S. Myung, "7-O-methylaromadendrin stimulates glucose uptake and improves insulin resistance in vitro," Biological \& Pharmaceutical Bulletin, vol. 33, no. 9, pp. 1494-1499, 2010.

[23] E. Elnajjar, S. Hasan, S. Al Zuhair, S. Al Omari, and A. HilalAlnaqbi, "Characterization and chemical composition of UAE date seeds," in Proceedings of the 2018 5th International Conference on Renewable Energy: Generation and Applications (ICREGA), pp. 56-60, Al Ain, UAE, February 2018.

[24] S. Sirisena, D. Zabaras, K. Ng, and S. Ajlouni, "Characterization of date (deglet nour) seed free and bound polyphenols by high-performance liquid chromatography-mass spectrometry," Journal of Food Science, vol. 82, no. 2, pp. 333-340, 2017.

[25] H. M. Habib, C. Platat, E. Meudec, V. Cheynier, and W. H. Ibrahim, "Polyphenolic compounds in date fruit seed (phoenix dactylifera): characterisation and quantification by using UPLC-DAD-ESI-MS," Journal of the Science of Food and Agriculture, vol. 94, no. 6, pp. 1084-1089, 2013.

[26] C. Platat, H. Habib, F. Theyab et al., "Identification of date seeds varieties patterns to optimize nutritional benefits of date seeds," Journal of Nutrition \& Food Sciences, vol. 8, no. 2, 2014.

[27] F. A. Juhaimi, K. Ghafoor, and M. M. Özcan, "Physical and chemical properties, antioxidant activity, total phenol and mineral profile of seeds of seven different date fruit (phoenix dactylifera L.) varieties," International Journal of Food Sciences and Nutrition, vol. 63, no. 1, pp. 84-89, 2012.

[28] S. Hilary, F. A. Tomás-Barberán, J. A. Martinez-Blazquez et al., "Polyphenol characterisation of phoenix dactylifera L. 
(Date) seeds using HPLC-mass spectrometry and its bioaccessibility using simulated in-vitro digestion/caco-2 culture model," Food Chemistry, vol. 311, Article ID 125969, 2019.

[29] H. Habib and W. Ibrahim, "Nutritional quality evaluation of eighteen date pit varieties," International Journal of Food Sciences and Nutrition, vol. 60, no. 1, pp. 99-111, 2009.

[30] C. Platat, H. Habib, A. Othman et al., "Safety and protective effetc of date (phoenix dactylifera) seed extract against oxidative damage in rat," International Journal of Food Sciences and Nutrition, vol. 4, no. 4, pp. 21-28, 2015.

[31] C. Platat, S. Hilary, F. Tomas-Barberan et al., "Urine metabolites and antioxidant effect after oral intake of date (phoenix dactylifera L.) seeds-based products (powder, bread and extract) by human," Nutrients, vol. 11, no. 10, pp. 2489-2507, 2019.

[32] P. P. McCue and K. Shetty, "Inhibitory effects of rosmarinic acid extracts on porcine pancreatic amylase in vitro," Asia Pacific Journal of Clinical Nutrition, vol. 13, no. 1, pp. 101-106, 2004.

[33] Y.-M. Kim, Y.-K. Jeong, M.-H. Wang, W.-Y. Lee, and H.-I. Rhee, "Inhibitory effect of pine extract on $\alpha$-glucosidase activity and postprandial hyperglycemia," Nutrition, vol. 21, no. 6, pp. 756-761, 2005.

[34] Y. Kwon, D. Vattem, and K. Shetty, "Evaluation of clonal herbs of lamiaceae species for management of diabetes and hypertension," Asia Pacific Journal of Clinical Nutrition, vol. 15, no. 1, pp. 107-118, 2006.

[35] V. Ani and K. A. Naidu, "Antihyperglycemic activity of polyphenolic components of black/bitter cumin centratherum anthelminticum (L.) kuntze seeds," European Food Research and Technology, vol. 226, no. 4, pp. 897-903, 2008.

[36] X. Han, T. Shen, and H. Lou, "Dietary polyphenols and their biological significance," International Journal of Molecular Sciences, vol. 8, no. 9, pp. 950-988, 2007.

[37] M. Toda, J. Kawabata, and T. Kasai, “ $\alpha$-Glucosidase inhibitors from clove (syzgium aromaticum)," Bioscience, Biotechnology, and Biochemistry, vol. 64, no. 2, pp. 294-298, 2000.

[38] C. Quesada, B. Bartolomé, O. Nieto, C. Gómez-cordovés, T. Hernández, and I. Estrella, "Phenolic inhibitors of $\alpha$-amylase and trypsin enzymes by extracts from pears, lentils, and Cocoa," Journal of Food Protection, vol. 59, no. 2, pp. 185-192, 1996.

[39] Q. He, Y. Lv, and K. Yao, "Effects of tea polyphenols on the activities of $\alpha$-amylase, pepsin, trypsin and LipaseEffects of tea polyphenols on the activities of $\alpha$-amylase, pepsin, trypsin and lipase," Food Chemistry, vol. 101, no. 3, pp. 1178-1182, 2007.

[40] T. Matsui, T. Ueda, T. Oki, K. Sugita, N. Terahara, and K. Matsumoto, " $\alpha$-Glucosidase inhibitory action of natural acylated anthocyanins. 1. Survey of natural pigments with potent inhibitory activity," Journal of Agricultural and Food Chemistry, vol. 49, no. 4, pp. 1948-1951, 2001.

[41] M. Bräunlich, R. Slimestad, H. Wangensteen, C. Brede, K. Malterud, and H. Barsett, "Extracts, anthocyanins and procyanidins from aronia melanocarpa as radical scavengers and enzyme inhibitors," Nutrients, vol. 5, no. 3, pp. 663-678, 2013.

[42] J. García-Alonso, G. Ros, and M. Jesús Periago, "Antiproliferative and cytoprotective activities of a phenolic-rich juice in HepG2 cells," Food Research International, vol. 39, no. 9, pp. 982-991, 2006.

[43] W. Yi, C. C. Akoh, J. Fischer, and G. Krewer, "Effects of phenolic compounds in blueberries and muscadine grapes on HepG2 cell viability and apoptosis," Food Research International, vol. 39, no. 5, pp. 628-638, 2006.
[44] S. Ramos, M. Alía, L. Bravo, and L. Goya, "Comparative effects of food-derived polyphenols on the viability and apoptosis of a human hepatoma cell line (HepG2)," Journal of Agricultural and Food Chemistry, vol. 53, no. 4, pp. 1271-1280, 2005.

[45] L. E. Rojo, D. Ribnicky, S. Logendra et al., "In vitro and in vivo anti-diabetic effects of anthocyanins from maqui berry (aristotelia chilensis)," Food Chemistry, vol. 131, no. 2, pp. 387-396, 2012.

[46] G. T. T. Ho, E. T. Kase, H. Wangensteen, and H. Barsett, "Phenolic elderberry extracts, anthocyanins, procyanidins, and metabolites influence glucose and fatty acid uptake in human skeletal muscle cells," Journal of Agricultural and Food Chemistry, vol. 65, no. 13, pp. 2677-2685, 2017.

[47] G. T. T. Ho, T. K. Y. Nguyen, E. T. Kase, M. Tadesse, H. Barsett, and H. Wangensteen, "Enhanced glucose uptake in human liver cells and inhibition of carbohydrate hydrolyzing enzymes by nordic berry extracts," Molecules, vol. 22, no. 10, pp. 1806-1820, 2017.

[48] P. Prabhakar and M. Doble, "Synergistic effect of phytochemicals in combination with hypoglycemic drugs on glucose uptake in myotubes," Phytomedicine, vol. 1, no. 16, pp. 1110-1126, 2009.

[49] H. Cao, M. M. Polansky, and R. A. Anderson, "Cinnamon extract and polyphenols affect the expression of tristetraprolin, insulin receptor, and glucose transporter 4 in mouse 3T3-L1 adipocytes," Archives of Biochemistry and Biophysics, vol. 459, no. 2, pp. 214-222, 2007.

[50] C.-Y. Hsu, H.-Y. Shih, Y.-C. Chia et al., "Rutin potentiates insulin receptor kinase to enhance insulin-dependent glucose transporter 4 translocation," Molecular Nutrition \& Food Research, vol. 58, no. 6, pp. 1168-1176, 2014.

[51] A. Collin, K. Dunlap, and T. Kuhn, "Alaskan blueberries and cranberries restore glucose uptake in a type 2 diabetes model," Federation of American Societies for Experimental Biology, vol. 31, pp. 970-1011, 2017.

[52] C. E. Park, M.-J. Kim, J. H. Lee et al., "Resveratrol stimulates glucose transport in $\mathrm{C} 2 \mathrm{C} 12$ myotubes by activating AMPactivated protein kinase," Experimental \& Molecular Medicine, vol. 39, no. 2, pp. 222-229, 2007.

[53] M. Naimi, T. Tsakiridis, T. C. Stamatatos, D. I. Alexandropoulos, and E. Tsiani, "Increased skeletal muscle glucose uptake by rosemary extract through AMPK activation," Applied Physiology, Nutrition, and Metabolism, vol. 40, no. 4, pp. 407-413, 2015.

[54] M. Minakawa, A. Kawano, Y. Miura, and K. Yagasaki, "Hypoglycemic effect of resveratrol in type 2 diabetic model $\mathrm{Db} / \mathrm{Db}$ mice and its actions in cultured L6 myotubes and RIN$5 \mathrm{~F}$ pancreatic $\beta$-cells," Journal of Clinical Biochemistry and Nutrition, vol. 48, no. 3, pp. 237-244, 2011.

[55] Y. Yamashita, M. Okabe, M. Natsume, and H. Ashida, "Cacao liquor procyanidin extract improves glucose tolerance by enhancing GLUT4 translocation and glucose uptake in skeletal muscle," Journal of Nutritional Science, vol. 1, pp. 2-3, 2019.

[56] M. Ueda, S. Nishiumi, H. Nagayasu, I. Fukuda, K.-i. Yoshida, and H. Ashida, "Epigallocatechin gallate promotes GLUT4 translocation in skeletal muscle," Biochemical and Biophysical Research Communications, vol. 377, no. 1, pp. 286-290, 2008.

[57] M. Koren-Gluzer, M. Aviram, and T. Hayek, "Paraoxonase1 (PON1) reduces insulin resistance in mice fed a high-fat diet, and promotes GLUT4 overexpression in myocytes, via the IRS-1/akt pathway," Atherosclerosis, vol. 229, no. 1, pp. 71-78, 2013.

[58] R. Kumar, S. Balaji, T. S. Uma, and P. K. Sehgal, "Fruit extracts of momordica charantia potentiate glucose uptake and up- 
regulate glut-4, PPAR $\gamma$ and PI3K," Journal of Ethnopharmacology, vol. 126, no. 3, pp. 533-537, 2009.

[59] F. Vlavcheski, D. Baron, I. Vlachogiannis, R. Macpherson, and E. Tsiani, "Carnosol increases skeletal muscle cell glucose uptake via AMPK-dependent GLUT4 glucose transporter translocation," International Journal of Molecular Sciences, vol. 19, no. 5, p. 1321, 2018.

[60] H.-M. Lee, O.-H. Lee, K.-J. Kim, and B.-Y. Lee, "Ginsenoside Rg1 promotes glucose uptake through activated AMPK pathway in insulin-resistant muscle cells," Phytotherapy Research, vol. 26, no. 7, pp. 1017-1022, 2012.

[61] H. Y. Kim and K. Kim, "Regulation of signaling molecules associated with insulin action, insulin secretion and pancreatic $\beta$-cell mass in the hypoglycemic effects of Korean red ginseng in goto-kakizaki rats," Journal of Ethnopharmacology, vol. 142, no. 1, pp. 53-58, 2012.

[62] P. Anand, K. Y. Murali, V. Tandon, P. S. Murthy, and R. Chandra, "Insulinotropic effect of cinnamaldehyde on transcriptional regulation of pyruvate kinase, phosphoenolpyruvate carboxykinase, and GLUT4 translocation in experimental diabetic rats," Chemico-Biological Interactions, vol. 186 , no. 1 , pp. $72-81,2010$.

[63] S. Faez, H. Muhajir, I. Amin, and A. Zainah, "Effects of oil palm (elais guineensis) fruit extracts on glucose uptake activity of muscle, adipose and liver cells," ASEAN Journal on Science and Technology for Development, vol. 31, no. 2, pp. 83-89, 2015.

[64] D. G. Hardie, "Sensing of energy and nutrients by AMPactivated protein kinase," The American Journal of Clinical Nutrition, vol. 93, no. 4, pp. 891S-896S, 2011.

[65] D. G. Hardie, F. A. Ross, and S. A. Hawley, "AMPK: a nutrient and energy sensor that maintains energy homeostasis," $\mathrm{Na}$ ture Reviews Molecular Cell Biology, vol. 13, no. 4, pp. 251-262, 2012.

[66] S. V. Penumathsa, M. Thirunavukkarasu, L. Zhan et al., "Resveratrol enhances GLUT-4 translocation to the caveolar lipid raft fractions through AMPK/akt/ENOS signalling pathway in diabetic myocardium," Journal of Cellular and Molecular Medicine, vol. 12, no. 6a, pp. 2350-2361, 2008.

[67] F. Hajiaghaalipour, M. Khalilpourfarshbafi, A. Arya, and A. Arya, "Modulation of glucose transporter protein by dietary flavonoids in type 2 diabetes Mellitus," International Journal of Biological Sciences, vol. 11, no. 5, pp. 508-524, 2015.

[68] G. J. McDougall and D. Stewart, "The inhibitory effects of berry polyphenols on digestive enzymes," BioFactors, vol. 23, no. 4, pp. 189-195, 2005. 